\title{
CONTENT MARKETING DECISIONS FOR THE CUSTOMER VALUE CREATION IN SOCIAL NETWORKS: ‘ILZENBERG MANOR’ CASE
}

\author{
Rūta Repovienė, Aušra Pažèraitè \\ Vytautas Magnus University, Lithuania \\ ruta.repoviene@vdu.lt; ausra.pazeraite@vdu.lt
}

\begin{abstract}
This article presents theoretical and practical aspects of content marketing decisions for the customer value creation in social networks by using the case of the organic farm 'Ilzenberg manor'. Focus of this paper is to determine which content marketing decisions create the biggest value for the customer in social networks.

The first part of the paper deals with theoretical insights into the content marketing decisions and their ability to create the customer value in social networks. Findings of theoretical analysis disclose that there are interfaces between content marketing, separate content marketing decisions and the customer value in the context of social networks. Respectively, it leads to an assumption that the usage of content marketing decisions can be valuable for the customer value creation in social networks.

The second part of the paper focuses on the case analysis of the organic farm 'Ilzenberg manor'. In order to determine which content marketing decisions create value for the customer in social networks, authors examine a correlation between separate content marketing decisions and consumer value indicators by using data from 'Ilzenberg manor' Facebook page.

The obtained results expose that not all content marketing decisions create value for the customer in social networks. Hence, it means that a selection of separate content marketing decisions in social networks can be made through the customer value perspective. The article ends with insights, conclusions, limitations and future research possibilities.
\end{abstract} Key words: content marketing, value for the customer, social networks, customer engagement.

\section{Introduction}

In the context of high competition, many companies are trying to conquer the market clutter using various types of marketing strategies. Many authors (Laric \& Lynagh, 2010; Kose \& Sert, 2017; Kannan, 2017; et al.) have admitted that nowadays the situation in the market is characterized by aggressive competition, information overload and more educated consumers. As a result, the fight for the consumer is fierce and complicated. It is not a secret that the prevalence of widespread social networking and digitization has also contributed to these conditions (Diaconu, Oancea, \& Brinzea, 2016; Kidane \& Sharma, 2016; Kannan, 2017). Therefore, it is widely recognized that creating value for a consumer is one of the main tasks for a competitive company (Woodruff, 1997; Ivanauskienè et al., 2012; McMurrian \& Matulich, 2006; Kumar \& Reinartz, 2016). Moreover, researchers (Ivanauskienè et al., 2012; Baltes, 2015) point out that the value for a consumer is not limited to the direct benefits of the product. Accordingly, it is important to look for new decisions, which can help to create value for the customer.

One of the newest and, considering the current market situation and challenges for companies, the most promising marketing strategy is content marketing. Over the past decade several articles have been published related to the content marketing concept (Kucuk \& Krishnamurthy, 2007; Steimle, 2014; Ahmad, Musa, \& Harun, 2016; et al.), application (Holliman \& Rowley, 2014; Baltes, 2015; Kose \& Sert, 2017; et al.) and its effect (Singh, 2016; Kidane \& Sharma, 2016; et al.). Nevertheless, despite the fact that the content marketing concept lays strong focus on value and value creation, there is lack of studies about the role of content marketing decisions in the customer value context. Discussions about the content marketing decisions for the customer value creation show the importance of knowing how they can be associated with, which content marketing decisions create value for the customer and how they can be used in different communication channels.

Considering all the discussed insights, the object of this research is content marketing decisions that serve the purpose of customer value creation The scientific problem analysed in the article is formulated by a question: how the content marketing decisions relate to the created customer value in social networks? The purpose of the research is to determine the strength of the relationship between the content marketing decisions and created customer value.

\section{Materials and Methods}

To achieve the purpose of the article, the analysis and synthesis of scientific literature in the fields of content marketing (Pulizzi, 2012; Holliman \& Rowley, 2014; Kose \& Sert, 2017; et al.), the customer value (Shanker, 2012; Ivanauskienè et al., 2012; McMurrian \& Matulich, 2006; Kumar \& Reinartz, 2016; et al.) and social networks (Lipsman et al., 2012; Ashley \& Tuten, 2015; Jaakonmäki, Müller, \& Brocke, 2017; et al.) are provided. In order to determine which content marketing decisions create value for the customer in social networks, the correlation analysis is conducted. The general scientific research methods 
were applied as well - systematic analysis, evaluation, generalization, comparison and abstraction.

\section{Theoretical substantiation}

The dramatically changing virtual environment has formed a competitive business setting, which provides opportunities for conducting business communication online (Kidane \& Sharma, 2016). Due to the developed and changing environment, organizations have understood the importance of marketing, because marketing is one of these fields that often employs technologies to improve activities and make everything better for more effective and efficient results (Khan \& Siddiqui, 2013; Järvinen \& Karjaluoto, 2015; Kose \& Sert, 2017). Companies must adapt to the new realities and challenges in business environment in which they exist and adopt the newest marketing strategies as the means by which they can develop long lasting relationships with both customers and stakeholders (Laric \& Lynagh, 2010; Archer-Brown, Piercy, \& Joinson, 2013; Diaconu, Oancea, \& Brinzea, 2016; Singh, 2016; Kannan, 2017; et al.). Moreover, the adoption of the newest marketing strategies can be understood much more broadly - not only as a survival tactic, but also as a way to win a customer.

One of the winning strategies offered by business and science (Pulizzi, 2012; Hanafizadeh \& Yarmohammadi, 2015; Kose \& Sert, 2017) is content marketing. Accordingly, there areplenty of marketing strategies that focus on content marketing to capture consumer's attention through unique, valuable, well produced and entertaining content, to make a more intense and significant impact than before (AguileraMoyano, Baños-González, \& Ramírez-Perdiguero, 2015). It is worth mentioning that content-based orientation is not really a new strategy and it is actually as old as any other marketing paradigm, but content marketing, as a purified concept and separate type of marketing, is still in the development phase (Pulizzi, 2012; Azad, AliAkbar, \& Zomorodian, 2016). Besides that, as Kose \& Sert (2015) emphasize, content marketing today is one of the most remarkable approaches in the context of marketing processes of companies. The value of this kind of marketing has improved over time, due to the latest developments in computer and communication technologies.

In scientific literature we can detect several types of content marketing definitions: from one of the earliest definitions 'Content marketing attracts potential consumers and increases their engagement and empowerment through the creation, dissemination and sharing of free content, relevant, meaningful, valuable and able to inspire confidence in existing and potential customers' given by S. Kucuk \& S. Krishnamurthy (2007), to one of the newest 'The content marketing is sharing the valuable information regarding the products and brands to attract others to participate in purchasing activities that create the engagement relationship between consumers and the companies' given by Ahmad, Musa \& Harun (2016). Obviously, those ten years of content marketing development did not dramatically affect the essence of its concept. According to J. Steimle (2014), the key factor in content marketing is value. He makes a short statement about this subject saying that 'You can tell if a piece of content is the sort that could be part of a content marketing campaign if people seek it out, if people want to consume it, rather than avoiding it' (Steimle, 2014). There is also an approach understanding content marketing as the means of value creation, putting a lot of weight on the conduit (Hanafizadeh \& Yarmohammadi, 2015). Such a view considers content as the means of producing value for the target audience. Therefore, it is clear that the main goal of implementing content marketing is to distribute valuable and consistent content to the target audience in order to stipulate the profitable consumer action. In other words, content marketing concept is based on an assumption that when enterprises provide valuable information for the customer, they can expect useful customer response.

Considering the previously discussed content marketing concept, it can be seen that the idea of content marketing has interface with the idea of the customer perceived value. Content marketing not only directly and indirectly relates to consumer value attributes (Pulizzi, 2012, Steimle, 2014; Kose \& Sert, 2015; Hanafizadeh \& Yarmohammadi, 2015; Ahmad, Musa, \& Harun, 2016; et al.), but also can be incorporated into the value for the customer creation process. Kumar \& Reinartz (2016) highlight that one of the most important marketing tasks is to create and communicate value to the customers to provoke their satisfaction, loyalty, and profitability.

Previous studies in the customer value field (Woodruff, 1997; Shanker, 2012; Ivanauskienè et al., 2012; McMurrian \& Matulich, 2006; Kumar \& Reinartz, 2016; Jiao, Jo, \& Sarigöllü, 2017; Fandrejewska, 2017; et al.) allow us to have some insight into what customer value is really about. It can be explained at different levels. At the lowest level, value for the customer can be viewed as an attribute of a product that customer perceives to receive value from (Woodruff, 1997; McMurrian \& Matulich, 2006; Kumar \& Reinartz, 2016). At a higher level, the customer value can be viewed as a social and emotional payoff and achievement of a goal or desire (Ivanauskienė et al., 2012; Fandrejewska, 2017). From content marketing perspective, Baltes (2015) refers to value for the customer as the creation of content that is interesting, draws customer's attention, 
and later transforms into long lasting relationships. Hence, if a company is able to create content that the customers find useful and valuable, the company has managed to create value (Holliman \& Rowley, 2014). For this reason, content development, which would be valuable for the target audience, should be a priority task in the marketing campaign planning process. However, in order to create value for the customer through content marketing, the issue of content distribution and particular decisions is also important. With more and more media platforms available, consumers have developed an insatiable demand for content. M. Diaconu, Oancea, \& Brinzea (2016) argue that the complex networks of friends, family, and peers now influence customers' purchase decisions. The new market winners will be the companies that excel at identifying and engaging with their customers across the social networks (Anderson et al., 2014; Ashley \& Tuten, 2015; Diaconu, Oancea, \& Brinzea, 2016; Jaakonmäki, Müller, \& Brocke, 2017). Social media is an innovative communication tool for retailers to interact with consumers. Brands and their consumers can now create two-way relationships and share content, news, and feedback (Lipsman et al., 2012). Additionally, consumers are willing to pay more to receive only those marketing messages that resonate with them, and they are receptive to those marketing messages that are valuable, short, focused and personally communicated by friends, trusted experts or favourite companies (Anderson et al., 2014). Jiao, Jo \& Sarigöllü (2017) agree by saying that the unique characteristics and universal popularity of social networks enable consumers to experience the customer value and thus improve their psychological well-being. Nevertheless, not all marketing activities and communication in social networks lead to high customer engagement. Creating effective content for social media marketing campaigns is a challenge, as companies have difficulty understanding what drives the user engagement (Jaakonmäki, Müller, \& Brocke, 2017).

Researchers (Merchant et al., 2014; Ashley \& Tuten, 2015; Diaconu, Oancea, \& Brinzea, 2016; Jaakonmäki, Müller, \& Brocke, 2017) highlight the main problematic areas that lead to low customer engagement: passive customers; information overload and low organic reach; lack of originality; primitive communication; focus on short-term goals; focus on the tangible aspects, not the emotional ones.

As a response to these problematic areas, $\mathrm{R}$. Jaakonmäki, Müller \& Brocke (2017) distinguish three key factors that lead to the customer engagement in social networks:

- The customer interfaces with the content creator (e.g. demographic characteristics, image, number of followers);
- Context of the content (e.g. time, place, topical issues);

- The main decisions of the content (e.g. visual and textual element).

The last factor is one of the most dependent on the communicating company. Despite the content marketing ability to create value for the customer, content marketing includes various types of decisions: how do we communicate? which content forms will we use? what is valuable for the customer? etc. (Ashley \& Tuten, 2015; Diaconu, Oancea \& Brinzea, 2016). Authors admit that social networks are favourable for various content marketing decisions, however, it is still not clear which content marketing decisions are the ones that can create the highest value for the customer.

\section{Research design}

In this study, correlation analysis is applied. Correlation is a bivariate analysis that measures the strength of association between two variables and the direction of the relationship. For correlation strength measurements, authors use Pearson's correlation coefficient, which shows the linear relationship between two sets of data and has no meaning for describing nonlinear relations.

Correlation is an effect size and so we can verbally describe the strength of the correlation using the guide that V. Kasiulevičius \& G. Denapienè (2008) suggest for the estimation of correlation coefficient ( $\mathrm{r}$ value) which describes only linear association (Table 1). In terms of the strength of linear relationship, the value of the correlation coefficient varies between +1 and -1 . A value of \pm 1 indicates a perfect degree of association between the two variables (Vakrina, 2007; Cohen et al., 2013). A value of 0 signifies that there is no linear relationship between the variables.

With this type of analysis, authors of this paper aim to examine the correlation between the number of certain content marketing decisions (independent variable $x$ ) and the number of distinguished customer value indicators (dependent variable $y$ ). The use of correlation analysis is appropriate since it measures the overall relationship between the two sets of variables. Despite the object of the research, this method was used in previous studies related to social networks (Malik et al., 2016), digital marketing (Aras et al., 2017) or customer value (Zameer et al., 2015). Correlation analysis and Pearson's correlation coefficient are known as the best method of measuring the relationships between variables of interest because it is based on the method of covariance. Moreover, it gives information about the magnitude of the correlation, as well as the direction of the relationship. 
Estimation of correlation coefficient ( $r$ value)

\begin{tabular}{|l|l|}
\hline \multicolumn{1}{|c|}{$r$ value $( \pm)$} & \multicolumn{1}{c|}{ Estimation } \\
\hline $.00-.19$ & very weak relationship \\
\hline $.20-.39$ & weak relationship \\
\hline $.40-.59$ & moderate relationship \\
\hline $.60-.79$ & strong relationship \\
\hline $.80-1.0$ & very strong relationship \\
\hline
\end{tabular}

Source: V. Kasiulevičius \& G. Denapienè (2008).

However, it should be noted, that correlation analysis itself does not reveal causes of the relationships between independent and dependent variables but evaluates the strength ( $r$ value) and statical significance (p-value) of correlation.

Facebook page of organic farm 'Ilzenberg manor' was taken for the field research to be performed. This particular farm, which is located in Lithuania, was chosen because of several reasons: a wide range of services and goods; a large number of followers (15 550); consistent communication and various forms of content marketing decisions in their posts. The main activity of 'Ilzenberg manor' is trade of organic food products and services for private recreation and celebration. The main target group is city residents who are interested in ecological lifestyle and like to be in nature. Until now, the main flow of followers was achieved organically.

In order to determine the linear relationship between content marketing decisions and created customer value indicators, data from Facebook posts of organic farm 'Ilzenberg manor' was collected. Research sample includes all posts from June to December of the year $2017(\mathrm{~N}=120)$. This period was chosen taking into account the peak of activity. Research was conducted in January, 2018.

The number of content forms (photos, emoji, hashtags, etc.) given in a particular post were counted as content marketing decisions (independent variable $x$ ). The number of the customer's reactions, comments, shares and post engagement rate was counted as the outcome - customers ' value perception (dependent variable $y$ ). Post engagement rate is derived as the total number of reactions, comments and shares for a particular post to the total number of page followers. Before correlation analysis, authors tested collected data in order to be sure, what data meet the main assumptions of the Pearson's correlation coefficient (e.g. absence of outliers, normality of variables etc.). MS Excel was used for data processing and correlation analysis.

\section{Results and Discussion}

Table 2 contains overall results of correlation analysis between different content marketing decisions and customers' value perception.
Analysis of 'Ilzenberg manor' Facebook posts indicates the strength of the relationship between the two variables and determines which content marketing decisions create the highest value for the consumer. During the research, the greatest attention was paid to the association between the content marketing decisions and the post engagement rate. Correlation results between the text lengths and created customer value indicator analysis shows a positive relationship -0.124 , with $p$-value of $<0.05$. It indicates a very week linear relationship and significance of the result obtained. Despite the fact that researchers and marketing experts (Merchant et al., 2014; Holliman \& Rowley, 2014; Kidane \& Sharma, 2016) say that internet users avoid long texts, conducted analysis revealed opposite results. Therefore, it provokes assumptions for deeper research.

Another content marketing decision, which was taken into account, is the number of photos. It was noted that the vast majority of the 'Ilzenberg manor' photos capture professional images of nature, manor surroundings and farm production. The result shows the highest positive $r$ value -0.714 , with $p$-value of $<0.05$. It shows that the usage of photos in Facebook posts is a very good tool to increase user's engagement, especially in case of reactions.

However, this is not valid for banners. The obtained correlation coefficient is negative $(r=-0.331)$ and $\mathrm{p}$-value is statistically highly significant $(\mathrm{p}<0.01)$. Hence, it means that usage of banners has a negative effect on user's engagement in the particular case. It could be explained by the fact that Facebook policy is to avoid banner-type posts and reduce organic reach. On the other hand, all banner-type posts from 'Ilzenberg manor' were very commercial.

In recent years, researchers and experts (Lipsman et al., 2012; Merchant et al., 2014; Kose \& Sert, 2017) have been highlighting the importance and advantages of video format in social networks. Notwithstanding, in this case video has no strong and significant linear realationship $(r=0.026 ; \mathrm{p} \geq 0.05)$. And even if the duration of the video has a weak positive correlation $(r=0.332)$ with user's engagement, result is not significant $(\mathrm{p} \geq 0.05)$ as well.

Correlation results between the number of emoji and user's engagement indicate the most negative 
Correlation between content marketing decisions and created customer's value perception

\begin{tabular}{|c|c|c|c|c|c|}
\hline \multicolumn{2}{|c|}{$\begin{array}{l}\text { Content marketing decision (unit of } \\
\text { measurement) }\end{array}$} & \multirow{2}{*}{$\begin{array}{r}\text { Reactions } \\
.138^{*}\end{array}$} & \multirow{2}{*}{$\begin{array}{r}\text { Comments } \\
.008^{*}\end{array}$} & \multirow{2}{*}{$\begin{array}{l}\text { Share } \\
.033^{*}\end{array}$} & \multirow{2}{*}{$\begin{array}{c}\begin{array}{l}\text { Post engagement } \\
\text { rate }\end{array} \\
.124^{*}\end{array}$} \\
\hline Text (characters (no spaces)) & $r=$ & & & & \\
\hline Photos (number of photos) & $r=$ & $.728^{*}$ & $.604 * *$ & $.453 * *$ & $.714^{*}$ \\
\hline Banners (number of banners) & $r=$ & $-.316^{* *}$ & $-.199 *$ & $-.296^{*}$ & $-.331 * *$ \\
\hline Video (number of video) & $r=$ & -.022 & $.188 *$ & $.191^{*}$ & .026 \\
\hline Video duration (in seconds) & $r=$ & .397 & $.329 * *$ & $.166^{*}$ & .332 \\
\hline Emoji (number of emoji) & $r=$ & $-.586^{* *}$ & $-.506 * * *$ & $-.556^{*}$ & $-.621 * *$ \\
\hline Hashtags (number of hashtags) & $r=$ & $.497 * *$ & $.177^{*}$ & $.517 * *$ & $.502 * *$ \\
\hline Sitelinks (number of sitelinks) & $r=$ & $-.420^{* *}$ & $-.396^{* *}$ & $-.343^{*}$ & $-.411 * *$ \\
\hline $\begin{array}{r}\text { External links (number of external } \\
\text { links) }\end{array}$ & $r=$ & -.019 & -.029 & .069 & -.010 \\
\hline Tags (numbers of tags) & $r=$ & .020 & -.025 & .009 & .167 \\
\hline $\begin{array}{r}\text { Action buttons (number of action } \\
\text { buttons) }\end{array}$ & $r=$ & -.170 & -.068 & -.136 & -.172 \\
\hline $\begin{array}{r}\text { Location tags (numbers of } \\
\text { location tags) }\end{array}$ & $r=$ & .336 & -.010 & .062 & .298 \\
\hline
\end{tabular}

Source: prepared by authors using the data provided by MC Excel.

$\mathrm{N}=120$

${ }^{*} \mathrm{p}<0.05 ; * * \mathrm{p}<0.01 ; * * * \mathrm{p}<0.001$

relationship. The correlation coefficient is $(-0.621)$ and the $\mathrm{p}$ value is $(<0.01)$. This shows that the result is highly significant. It also indicates that if the firm uses a lot of emoji, it will adversely affect user's engagement.

In the analyzed posts, hashtags have been frequently used (3.7 hashtags per post). Usually, hashtags mark specific themes, products, slogans, type of the content or brand name, e.g.: \#cheese, \#beautifulnature, \#noconservant, etc. This kind of tagging makes it possible for the customers easilyfind messages with a specific theme or content (Lipsman et al., 2012; Azad, AliAkbar, \& Zomorodian, 2016). Moreover, it could be used not only as a tag, but as a short message form as well. Accordingly, the association between the number of hashtags and user's engagement was moderately strong and positive $(r=0.502)$ and statistically highly significant $(\mathrm{p}<0.01)$.

In terms of links usage, analysis revealed noticeable results. Various authors (Archer-Brown, Piercy, \& Joinson, 2013; Aguilera-Moyano, Baños-González, \&
Ramírez-Perdiguero, 2015) note that the use of links, especially to other websites, is not a good step from the perspective of valuable content creation. But in 'Ilzenberg manor' case, results indicate a different situation. Both sitelinks and external links have no positive effect on user's engagement. Therefore, the effect of the inner link was much stronger $(r=-0.411)$ and statistically highly significant $(\mathrm{p}<0.01)$. This may be because of the fact that most of the sitelinks were focused on direct sales.

By assessing the numbers of tags $(r=0.167)$, action buttons $(r=-0.172)$ and location tags $(r=0.298)$ linear relationship with user's engagement, authors of this paper did not notice any strong and/or statistically significant correlation. It indicates that these content marketing decisions are not useful for the customer value creation.

Taking all the aforementioned into account, it could be stated that the application of different content marketing decisions throughout Facebook posts indicates linear relationship with user's engagement. 
Although, not all the relationships are positive or significant, thus the choice of content marketing solution should be made deliberately in order to create value for the customer chosen.

\section{Conclusions}

1. Due to the worldwide digitization, information overload, increased competition, changed customer habits and globalization, companies are constantly looking for new ways to become more successful. Marketing activities are perceived as one of those ways. However, marketing itself does not guarantee a good result and victory in the battle for the customer. Therefore, new and more effective marketing strategies are being developed. One of the newest marketing trends and types is content marketing.

2. Theoretical substantiation shows that the main idea of applying content marketing is to create valuable content to the target audience in order to facilitate profitable customers' actions. Literature review also reveals that one of the content marketing keywords is value for the customer. Thus, there are connections between content marketing and value for the customer creation, especially in the context of emotional and social value. Therefore, the application of content marketing decisions in social networks, one of the most popular media channels, can create the customer value and increase customer's engagement.
3. In order to indicate the strength of the association between the two variables and determine which content marketing decisions create the highest value for the consumer in social networks, correlation analysis was performed. Analysis of the obtained results makes it possible to conclude that if a company wants to increase customer's engagement as the indicator of customer value, content creation decisions should include the usage of photos and hashtags when posting. However, the research revealed that some decisions can have a negative effect on the customer perceived value. These are the number of banners, emoji's and links which should be reduced. It could be noted, that strong and significant linear relationship between some content marketing decisions, such as the number of actions buttons, tags or location tags, and the customer value does not exist.

4. Restrictions of this research offer some opportunities for further research. Considering the fact that there are several content marketing decisions applied in one post, it is necessary to expand the field of study by examining relationships between various combinations of content marketing decisions and customers' engagement. Moreover, the expansion of the cases to be investigated and the assessment of post messages can be included as well.

\section{References}

1. Aguilera-Moyano, J., Baños-González, M., \& Ramírez-Perdiguero, J. (2015). Branded Entertainment: Entertainment content as marketing communication tool. A study of its current situation in Spain. Revista Latina de Comunicación Social, 70, 519-538. DOI: 10.4185/RLCS-2015-1057en.

2. Anderson, K.C., Knight, D.K., Pookulangara, S., \& Josiam, B. (2014). Influence of hedonic and utilitarian motivations on retailer loyalty and purchase intention: a facebook perspective. Journal of Retailing and Consumer Services, 21(5), 773-779. DOI: 10.1016/j.jretconser.2014.05.007.

3. Aras, M., Syam, H., Jasruddin, J., Akib, H., \& Haris, H. (2017). The Effect of Service Marketing Mix on Consumer Decision Making. Proceedings of International Conference on Education, Science, Art and Technology, 108-112. Retrieved April 26, 2018, from: http://ojs.unm.ac.id/icesat/article/view/3690/2101.

4. Archer-Brown, C., Piercy, N., \& Joinson, A. (2013). Examining the information value of virtual communities: Factual versus opinion-based message content, Journal of Marketing Management, 29(3-4), 421-438. DOI: 10.1080/0267257X.2012.732599.

5. Ashley, C., \& Tuten, T. (2015). Creative strategies in social media marketing: An exploratory study of branded social content and consumer engagement. Psychology \& Marketing, 32(1), 15-27. DOI: 10.1002/ mar.20761.

6. Azad, N., AliAkbar, S., \& Zomorodian, S. (2016). Factors stimulating content marketing. Management Science Letters, 6(2), 109-114. DOI: 10.5267/j.msl.2016.1.002.

7. Baltes, P.L. (2015). Content marketing- the fundamental tool of digital marketing. Series V: Economic Sciences, 57 (8), 111118. Retrieved March 6, 2018, from: http://webbut.unitbv.ro/BU2015/Series\%20V/ BILETIN\%20I/15_Patrutiu.pdf.

8. Cohen, J., Cohen, P., West, S.G., \& Aiken, L.S. (2013). Applied multiple regression/correlation analysis for the behavioral sciences. New Jersey: Routledge. 
9. Diaconu, M., Oancea, O., \& Brinzea, M. (2016). Integrated marketing communication, instrument of modern organizations development in terms of sustainability. Ecoforum Journal, 5(2), 270-277. Retrieved March 1, 2018, from: http://www.ecoforumjournal.ro/index.php/eco/article/view/417/264.

10. Fandrejewska, A. (2017). Understanding consumer ssentiments as a key to creating superior the customer value. Handel Wewnętrzny, 368(3), 275-286. Retrieved February 14, 2018, from: https:/www.ceeol.com/ search/article-detail?id=595150.

11. Hanafizadeh, P., \& Yarmohammadi, M. (2015). An integrated conceptualization of content in an information society. Information development, 10(1), 1-10. DOI: 10.1177/0266666915572926.

12. Holliman, G., \& Rowley, J. (2014). Business to business digital content marketing: marketers perceptions of best practice. Journal of Research in Interactive Marketing, 8(4), 269-293. DOI: 10.1108/JRIM-022014-0013.

13. Ivanauskienė, N., Auruškevičienè, V., Škudiene, V., \& Nedzinskas, Š. (2012). The customer perceptions of value: case of retail banking. Organizations and markets in emerging economies, 5(1), 74-87. Retrieved February 16, 2018, from: http://www.om.ef.vu.lt/cms/cache/RePEc_files/article_30.pdf.

14. Jaakonmäki, R., Müller, O., \& Brocke, J. (2017). The Impact of Content, Context, and Creator on User Engagement in Social Media Marketing. Proceedings of the 50th Hawaii International Conference on System Sciences, 1152-1160. DOI: 10.24251/HICSS.2017.136

15. Järvinen, J., \& Karjaluoto, H. (2015). The use of web analytics for digital marketing performance measurement. Industrial Marketing Management, 50, 117-127. DOI: 10.1016/j.indmarman.2015.04.009.

16. Jiao, Y., Jo, M.S., \& Sarigöllü, E. (2017). Social Value and Content Value in Social Media: Two Paths to Psychological Well-Being. Journal of Organizational Computing and Electronic Commerce, 27(1), 3-24. DOI: 10.1080/10919392.2016.1264762.

17. Kannan, P.K. (2017). Digital marketing: A framework, review and research agenda. International Journal of Research in Marketing, 34(1), 22-45. DOI: 10.1016/j.ijresmar.2016.11.006.

18. Kasiulevičius, V., \& Denapienė, G. (2008). Statistikos taikymas mokslinių tyrimų analizèje (Statistics In Scientific Research Analysis). Gerontologija, 9(3), 176-180. Retrieved March 6, 2018, from: http://www. gerontologija.lt/files/edit_files/File/pdf/2008/nr_3/2008_176_180.pdf. (in Lithiuanian).

19. Khan, F., \& Siddiqui, K. (2013). The importance of digital marketing. An exploratory study to find the perception and effectiveness of digital marketing amongst the marketing professionals in Pakistan. Journal of Information Systems \& Operations Management, 7(2), 12-19. Retrieved March 2, 2018, from: http:// www.rebe.rau.ro/RePEc/rau/jisomg/WI13/JISOM-WI13-A2.pdf.

20. Kidane, T.T., \& Sharma, R.R.K. (2016). Factors affecting consumers' purchasing decision through e-commerce. Retrieved February 27, 2018, from: http://ieomsociety.org/ieom_2016/pdfs/52.pdf.

21. Kose, U., \& Sert, S. (2017). Improving content marketing processes with the approaches by artificial intelligence. Eforum, 6(1), 18. Retrieved February 22, 2018, from: https://arxiv.org/ftp/arxiv/ papers/1704/1704.02114.pdf.

22. Kucuk. S., \& Krishnamurthy, S. (2007). An Analysis of Consumer Power on the Internet. Technovation, 27 (1-2), 47-56. DOI: 10.1016/j.technovation.2006.05.002.

23. Kumar, V., \& Reinartz, W. (2016). Creating enduring the customer value. Journal of Marketing, 80(6), 36-68. DOI: 10.1509/jm.15.0414.

24. Laric, M.V., \& Lynagh, P.M. (2010). The Role of Integrated Marketing Communications in Sustainability Marketing. American Society of Business and Behavioral Sciences, 17(1), 108-119. DOI: 10.1080/15280080902988048.

25. Lipsman, A., Mudd, G., Rich, M., \& Bruich, S. (2012). The power of "like": How brands reach (and influence) fans through social-media marketing. Journal of Advertising research, 52(1), 40-52. DOI: 10.2501/JAR-52-1-040-052.

26. Malik, A., Dhir, A., \& Nieminen, M. (2016). Uses and gratifications of digital photo sharing on Facebook. Telematics and Informatics, 33(1), 129-138. DOI: 10.1016/j.tele.2015.06.009.

27. McMurrian, R.C., \& Matulich, E. (2006). Building the customer value and profitability with business ethics. Journal of Business \& Economics Research, 4(11), 11-18. Retrieved January 26, 2018, from: https://www. researchgate.net/profile/Robert_Mcmurrian/publication/255610639_Building_The customer_Value_ And_Profitability_With_Business_Ethics/links/540deffb0cf2d8daaacd3974.pdf.

28. Merchant, G., Weibel, N., Patrick, K., Fowler, J.H., Norman, G.J., Gupta, A., \& Donohue, M. (2014). Click "like" to change your behavior: a mixed methods study of college students' exposure to and engagement with Facebook content designed for weight loss. Journal of medical Internet research, 16(6), 777-780. DOI: $10.2196 /$ jmir.3267. 
29. Pulizzi, J. (2012). The rise of storytelling as the new marketing. Publishing Research Quarterly, 28(2), 116-123. DOI: 10.1007/s12109-012-9264-5.

30. Shanker, A. (2012). What is the customer value and how do you deliver it? Technology Innovation Management Review, 2(2), 32-33. Retrieved February 14, 2018, from: http://timreview.ca/article/525

31. Singh, R. (2016). Creating engaging library experiences through effective content marketing. OLA Quarterly, 21(4), 49-54. DOI: 10.7710/1093-7374.1838.

32. Steimle, J. (2014). What is content marketing? Retrieved February 2, 2018, from: http://www.forbes.com/ sites/joshsteimle/2014/09/19/what-is-content-marketing/\#11393b331d70.

33. Vakrina, E. (2007). Matematinès statistikos pradmenys. Statistinių duomenų analizè naudojant MS EXCEL (The basics of mathematical statistics (Statistical analysis by using MS EXCEL). Retrieved January 6, 2018, from: http://olgal.home.mruni.eu/wp-content/uploads/2008/04/mat_stat_excel.doc. (in Lithiuanian).

34. Woodruff, R.B. (1997). The customer value: the next source for competitive advantage. Journal of the academy of marketing science, 25(2), 139-153. DOI: 10.1177\%2F0092070397253006.

35. Zameer, H., Tara, A., Kausar, U., \& Mohsin, A. (2015). Impact of service quality, corporate image and customer satisfaction towards customers' perceived value in the banking sector in Pakistan. International journal of bank marketing, 33(4), 442-456. DOI: 10.1108/IJBM-01-2014-0015. 